DOI: 10.20472/IAC.2019.052.040

DANIEL FRANCOIS MEYER

TRADE Research Unit, NWU, South Africa

\title{
AN EMPIRICAL ANALYSIS OF THE IMPACT OF EMPLOYMENT, WAGES AND INFLATION ON CONSUMER SPENDING IN A DEVELOPING COUNTRY, SOUTH AFRICA
}

\begin{abstract}
:
Real income, rising inflation and low levels of formal employment have a significant impact on consumers. This study has the objective to assess the impact of real income, inflation, productivity and low levels of employment on consumer in South Africa, which is a proxy for developing countries. This study is important due to the high levels of unemployment in South Africa and the fact that consumers are under immense pressure also due to rising inflation, low income levels, low levels of productivity and rising unemployment. The research is based on the Keynesian theoretical approach of aggregate demand where demand by consumers and other components of spending drives economic growth. A quantitative research methodology was utilized using quarterly time series data from 2000 to 2018. The study attempted to determine both the long and short-run relationship between the selected variables, using econometric models such as Johansen cointegration and ARDL models with consumer spending as dependent variable with real income, inflation, productivity and employment as independent variables. Results from the econometric analysis indicated long-run relationships between the variables. Results from a short-run perspective indicate that consumer spending in the short run is positively significant to employment, real income and inflation. Employment, both formal and informal employment should be facilitated and promoted by means of enabling environment policy development. Also, income levels for the lower income earners should be increased to enhance consumer spending and ultimately contributing to economic growth. It should also be a policy guideline to ensure growth in productivity is above growth in income.
\end{abstract}

\section{Keywords:}

Consumer spending, employment, income, inflation, productivity, South Africa.

JEL Classification: C10, D12 


\section{INTRODUCTION}

Consumer spending contributes more than $60 \%$ to aggregate spending in an economy and is seen as a key driver of the economy (Toossi, 2002; Barello, 2014). Consumers in South Africa have been under pressure since the financial crises in 2008-2009, due to low levels of employment, low levels of income if employed, and rising living costs. For example, the fuel price has increased from $R 6.01$ in 2009 to $R 15.81$ in 2019 relating to an average annual increase of $16.3 \%$, while electricity cost has increased by $35 \%$ on average per annum. The unemployment rate in South Africa has been increasing over the last decade and has reached a peak of more than 29\% in 2019 (StatsSA, 2019). Possible employment for low skilled workers are finding the process of obtaining and securing employment increasingly difficult. The majority of those people that have been employed in South Africa are working for low wages resulting in high levels of income inequality with an extremely high Gini coefficient of 0.63 (TradingEconomics, 2019). Due to the high levels of unemployment and low wages the consumer spending component within the South African economy is not contributing effectively to aggregate demand.

Long term unemployment is a serious socio-economic problem as it has an influence on economic growth, production, erosion of human capital, social exclusion, crime and social instability. The International Labour Organisation (ILO, 1996, 2000, 2017) reported that a large majority of people in the South African labour market do not have access to any income or receive low levels of income and unemployment is a long-run structural problem.

It is important to understand how a particular household or individual consumer adjusts their expenditure in the face of worsening labour market conditions. Long term unemployment and consumer spending has a direct effect on fiscal policy because of the impact on government revenue and expenses through taxes and transfers. According to Kanawo and Lalumia (2004) a decrease in consumer spending related to an increase in long term unemployment, put severe pressure on government budgets, especially during the periods of recession. Consumer spending by those people that are permanently or temporarily employed in any form is likely to differ from the spending pattern of those who are unemployed (Knight, 1982).

The study analyses the relationship between consumer spending and other variables such as employment levels, real income through wages and inflation. There are various theories which explains the causes, the correlation and consequences of long term unemployment on consumer spending. If individuals were previously employed and lost their jobs in due course, spending is expected to decline, the response of unemployment to consumer spending is always a negative one (Oswald, 2009).

\section{LITERATURE REVIEW}

The South African business sector which includes the retail and manufacturing sectors, continues to be negatively affected by an ineffective consumer market due to a lack of spending and demand for goods according to a recent report by Statistics South Africa (2018). According to Mankiw (1985) consumer spending is what households purchase to fulfil their everyday needs. Consumer goods that is purchased, creates demand that keeps companies profitable and allowing for the hiring new employees (Ross, Weill \& Robertson, 2006). In relation to long term unemployment, the permanent income hypothesis theory explains how consumers use their income. The theory states that changes in income can 
change the spending pattern of a consumer. Furthermore, unemployment also prevents smooth spending patterns (Mankiw, 1985). In addition, the theory of permanent income hypothesis states that consumers will spend money at a level that is specific to their expected long term average income. The theory holds the assumption that there will not be an increase in consumer spending until consumers are certain about their income expectations (Kitson, 1997).

According to Bhorat (1991) long-term unemployment or low levels of employment, refers to people who have been unemployed for 12 months or more. High rate of long term unemployment indicates that labour markets are operating inefficiently, hindering effective consumer spending. Long term unemployment alters how consumers plan their spending as it forces consumers to spend carefully, and this is a deprivation to the economy as a whole. The presence of long term unemployment can lead to negative impacts on businesses, because less spending implies less profit (Thoodosioou, 1998).

Studies show that consumer spending is responsive to income levels (Baker, 2015; Zheng \& Henneberry, 2011). The economy can grow if individuals have a source of income. If consumer spending decreases, business growth is low and this may lead to more unemployment if business decided to liquidate or close down (Rode, 2012). A decrease in consumer spending has a deflationary impact on the economy (Wilkelmann, 1998). The level of employment is one of the factors which affects consumer spending, as a steady income has a positive impact on consumer spending. According to Angeletos et al. (2001) consumer spending is mainly dependent on real disposable income which is income after direct taxes and welfare benefits. The most important factor is the rate at which consumers increase their spending as income increases. If wages increase faster than inflation, then real income will increase and this leads to a higher level of real purchasing power, that is the value of currency in terms of the amount of goods or services that a single unit of money can purchase (Sarno \& Taylor, 2002). People who are not employed would consume less because of their low purchasing power resulting in low growth (Thomson, 1998).

Consumers' propensity to spend rather than save are negatively affected by inflation and even expectations of changes in inflation (Mankiw, 1985). In the relationship between unemployment and the rate of change of wage, Phillips concludes that there is a stable relationship that exists between unemployment and rates of wages (Alisa, 1990). The Phillips curve explains the relationship between the unemployment rate and inflation and indicates a negative relationship (Gallegati et al., 2011). Inflation has a negative effect on the value of money. A lower inflation rate implies that the price of goods and services will gradually increase at a slower rate. In this context the Phillips curve has been an important consideration for policy and decision makers as well as the central banks (Mankiw, 1985).

According to Stephans (2011), Keynesian economics emphasises on the cyclical nature of unemployment and suggests government intervention in the economy can possibly reduce the shock of unemployment. The focus of the Keynesian theory is on recurrent shocks that reduces aggregate demand for goods and services and less employment opportunities. Government should attempt to facilitate full employment through fiscal, monetary and trade policy (Kreishan, 2011). According to Sklair (2017) consumer spending in developed countries has been intensively studied along with the modernisation process. He found that consumer spending per capita in developed countries has increased by about $2.3 \%$ per annum over the past 25 years. In China, a developing country, with its rapid economic 
growth environment, the rising incomes in urban regions, caused consumer spending to double over the period 1980 to 1994 . India is another country which experienced an increase in the rate of consumer spending with increased income. Despite the increased income levels in developing countries such as in Asia, only 21 developing countries registered increasing consumer spending levels (Sklair, 2017).

Hausman and Wieland (2014) also indicated in developed countries such as the USA, unemployment spells are usually short and the decline in consumer spending is normally limited and only temporary in nature. According to them, the key success in the job markets in Africa is two sided. Firstly, growth in the agriculture sector especially in exports positively affects the rural labour market as well as for the urban labour market due to increased demand for products. Secondly, a focus on the growth of the manufacturing sector could lead to employment opportunities due to an increase in exports. There are certain countries in Africa that have succeeded using this policy dimensions and there are those which never succeeded in both policies. The findings in the Ghanian case study reveal that there is a positive association between inflation and consumer spending in Ghana which supports studies conducted previously by Alisa (1990), however those findings are contrary to the ones conducted by Bachmann et al. (2015) showing that there is a negative relation between the two variables in the case of Ghana. Policy makers should therefore take into consideration both the findings since inflation induces consumer spending behaviour.

Shapiro and Slemrod, (1993) analysed consumer spending in the case where consumers received an increase in income. The study found that $43 \%$ of consumers spent less than the extra income received, indicating the uncertainty and difficulty in predicting consumer behaviour. This indicates that household spending is not always consistent with the lifecycle/permanent-income model. Parker et al., (2013), measured changes in household spending after periods of government economic stimulus. The study found that households spend significantly more on durable goods in such periods of stimulus.

Agarwal, Liu, and Souleles (2007), analysed in impact of income tax rebates on consumer spending. The study found that consumers saved some portion of the tax rebate and by paying off debt. But after the initial saving period, spending by consumers increased to higher levels. Consumers with a past records of over-spending continued to spend more than more effective and saving inclined consumers. Ganong and Noel, (2015) and also a second study in 2019, found in the US that unemployment causes a reduction in income of more than $6 \%$ but as unemployment insurance kicks in, the overall spending reduces by only $1 \%$. Spending then reduces significantly when the insurance is exhausted. The study also found that consumer spending is highly correlated with income. Mian and Sufi (2014), also analysed consumer spending in the US. The results indicate that reduced spending had a significant impact on employment during the financial crises of 2007 and 2009. Midrigan and Philippon, (2011) found that for regions during a recession where large decines in consumer spending were experienced, had the highest negative impact on economic output as well as in employment levels.

\section{METHODOLOGY}

This study methodology follows the functionalist research paradigm and is based on a quantitative research approach, using an econometric model. In achieving the main objective of the study to determine the impact of selected factors on consumer spending, secondary 
time series quarterly data were collected. A total number of 90 quarterly observations from the first quarter of 1997 to the second quarter of 2019 were included. The study is based on the South African context. The following variables are included in the study; Total consumer spending (CONSP), employment levels (EMPL), real wage levels (WAGES), consumer price index (CPI) and consumer vulnerability (CONVUL). Data regarding all of the variables were obtained from the South African Reserve Bank (SARB)(2019) and Statistics South Africa (StatsSA)(2018). All variables were converted to natural logarithms to ensure the results are comparable on similar scales. Thus, the model can be expressed as follows:

LCONSP $=\mathrm{f}($ LEMPL, LWAGES, LCPI, LCONVUL).

A Vector Auto-regression (VAR) approach was used in the study. Such a model analyses changes to endogenous variables in a model, based on a specific time period as a linear function. This model is useful as all of the variables forms part of aprocess of regression, firstly on the variables own lagged values as well as on the lagged values of other variables included in the model. A VAR model therefore is ideal in analysing the relationships between all of the variables used in a study for multivariate analysis (Brooks, 2014). In order to decide which econometric model to be used in a study, an important process is to determine the integration order of variables or unit root tests for stationarity. In this study the Augmented Dickey Fuller (ADF) test (1979) was used to determine the order of integration. Depending on order of integration of variables, the next step is to test for long-run cointegration of the variables, via either the Johansen cointegration (stationarity at $1^{\text {st }}$ difference) or ARDL (mixed stationarity) models. The next step in the process is to confirm the long-run relationships and to test for short-run relationships between the variables using a vector error correction model (VECM). This process also determines the speed of adjustment towards the re-establishment of equilibrium (Brooks, 2014). In order to test for causality between variables, pair-wise Granger causality tests were conducted to identify the direction of relationships between variable. Lastly, residual diagnostic tests are estimated in order to assess the stability of the model and ensure viable results.

\section{RESULTS AND DISCUSSION}

This section starts with a descriptive trends analysis as depicted in Figure 1. Consumer spending as measured in constant prices, shows a constant increase in spending with a few breaks of shocks from 1997 to 2019. In 1998 consumer spending stagnated while spending during the 2008-2009 financial crises declined dramatically, but recovered by 2011 . Since 2012 up to 2019 spending has increased but an at declining rate. Over the total period from 1997 to 2019, the annual average growth rate was 4.1\%. Since 2011 to 2019, consumer spending has slowed down to $1.9 \%$ per annum. The employment index indicates a volatile situation over the same period, with a low point reached in 2003 , while the highest value achieved in 2014. Since the financial crises in 2008-2009, the employment situation in the country has not really recovered and the graph shows only a slight increase over time. Employment growth over the total period was 0.6\% per annum and since 2011 the annual growth was $0.5 \%$ indicating the slowdown in employment opportunities. Real wages have shown a steady and constant increase across the period under investigation, but with a declining trend since the beginning of 2019. Overall annual average growth in the index over the total period was a high $22.7 \%$. CPI also had a steady increase across the study period with an average annual increase of $10.5 \%$. Consumer vulnerability is a measurement from 0 to 100 (high values relate to higher levels of vulnerability) and the graph shows high levels of 
volatility. The lowest level of vulnerability was reached in 2004 and high levels was achieved in 2009. Since 2011, the vulnerability index hovered around the 50 mid-mark line.

\section{Figure 1: Trend analysis}

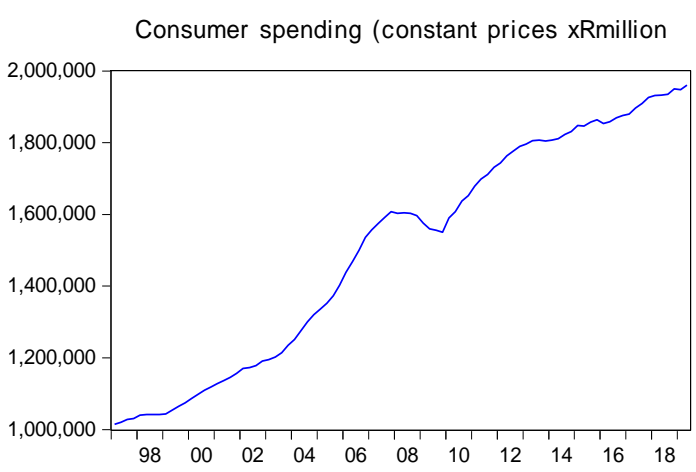

Real wages index

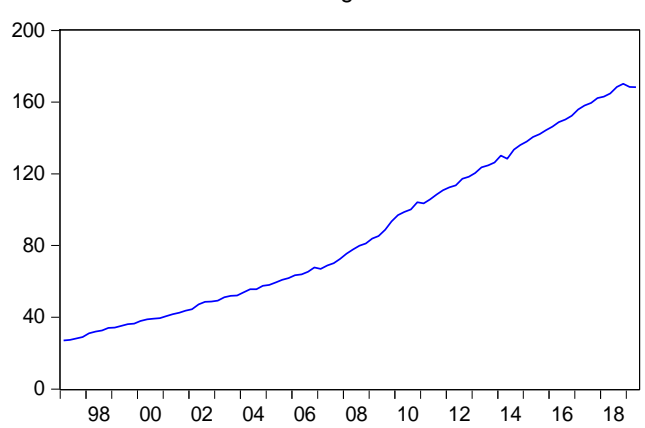

Consumer vulnerability index (out of 100)

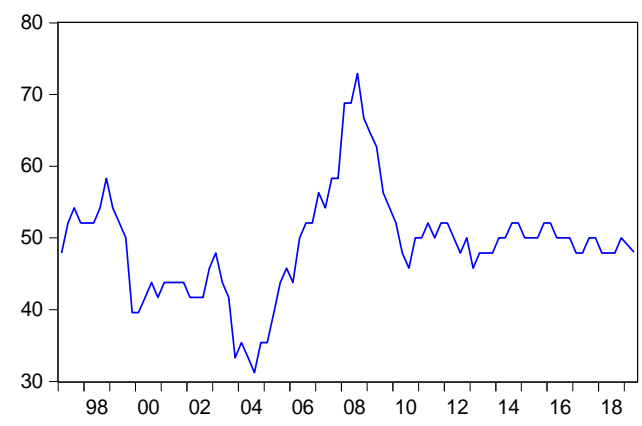

Employment index

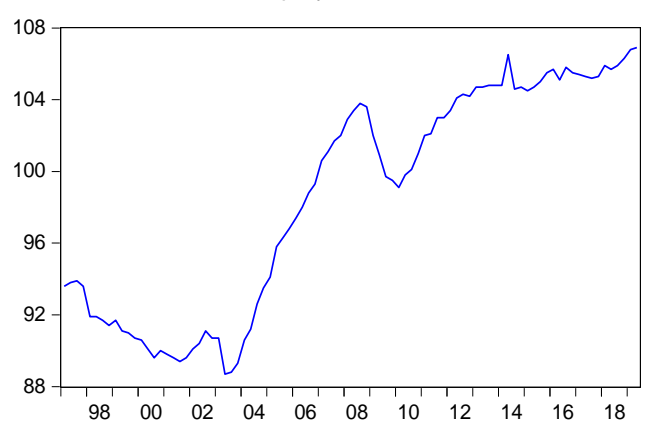

CPI

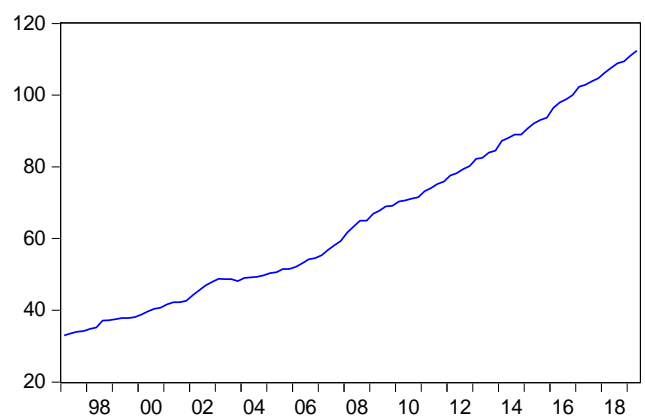


Table 1 presents the correlation analysis including correlation coefficients and p-values. When focussing on the dependent variable namely consumer spending, it has positive and significant relationships with all of the independent variables. This means that on the shortrun an increase in spending cause increase in employment, increase in wages and increase in inflation levels. The consumer vulnerability index has a negative correlation in relation to the other variables.

Table 1: Correlation analysis

\begin{tabular}{|c|c|c|c|c|c|}
\hline Variables & $\begin{array}{l}\text { Consumer } \\
\text { spending }\end{array}$ & $\begin{array}{l}\text { Employment } \\
\text { index }\end{array}$ & $\begin{array}{l}\text { Real wages } \\
\text { index }\end{array}$ & $\mathrm{CPI}$ & $\begin{array}{c}\text { Consumer } \\
\text { vulnerability }\end{array}$ \\
\hline \multirow[t]{3}{*}{$\begin{array}{l}\text { Consumer } \\
\text { spending }\end{array}$} & 1.000 & & & & \\
\hline & ----- & & & & \\
\hline & ----- & & & & \\
\hline \multirow[t]{3}{*}{$\begin{array}{c}\text { Employment } \\
\text { index }\end{array}$} & 0.9589 & 1.0000 & & & \\
\hline & 31.7353 & ---- & & & \\
\hline & $0.0002^{*}$ & ---- & & & \\
\hline \multirow[t]{3}{*}{$\begin{array}{c}\text { Real wages } \\
\text { index }\end{array}$} & 0.9616 & 0.9010 & 1.0000 & & \\
\hline & 32.8967 & 19.4938 & ----- & & \\
\hline & $0.0003^{*}$ & $0.0005^{*}$ & ----- & & \\
\hline \multirow[t]{3}{*}{$\mathrm{CPI}$} & 0.9605 & 0.8986 & 0.9981 & 1.0000 & \\
\hline & 32.4179 & 19.2119 & 151.9539 & ----- & \\
\hline & $0.0002^{*}$ & $0.0007^{*}$ & $0.0001^{*}$ & ----- & \\
\hline \multirow[t]{3}{*}{$\begin{array}{l}\text { Consumer } \\
\text { vulnerability }\end{array}$} & -0.2772 & -0.4648 & -0.1662 & -0.1818 & 1.0000 \\
\hline & -2.7065 & -4.9257 & -1.5813 & -1.7349 & ----- \\
\hline & $0.0082^{*}$ & $0.0023^{*}$ & 0.1174 & 0.0862 & ---- \\
\hline
\end{tabular}

Note: * Correlation at the $5 \%$ significance level. () indicates $p$-value.

Table 2 indicates the results of the ADF Unit root tests. The results indicate that all variables are stationary at $1^{\text {st }}$ difference or $\mathrm{I}(1)$. This results therefore confirms the use of the Johansen cointegration test to analyse the long-run relationships between the variables. The results of the lag-length selection criteria indicate either a lag selection of five (5) or one (1) lag as the optimum number of lags to be used in the model.

Table 2: ADF Unit root test results

\begin{tabular}{|l|l|l|l|}
\hline Variable & $\begin{array}{l}\text { Levels I(0) (ADF test) (p- } \\
\text { value in brackets) }\end{array}$ & $\begin{array}{l}\text { First Difference I(1) (ADF } \\
\text { test)(p-value in brackets) }\end{array}$ & Result \\
\hline
\end{tabular}




\begin{tabular}{|l|l|l|l|}
\hline LCONSP & $-1.2134(0.6639)$ & $-1.8766\left(0.0498^{\star}\right)$ & $\mathrm{I}(1)$ \\
\hline LEMPL & $-0.6329(0.8568)$ & $-3.9772\left(0.0024^{\star}\right)$ & $\mathrm{I}(1)$ \\
\hline LWAGES & $-0.0372(0.9962)$ & $-9.3105\left(0.0003^{\star}\right)$ & $\mathrm{I}(1)$ \\
\hline LCPI & $-0.6424(0.8529)$ & $-4.4632\left(0.0005^{\star}\right)$ & $\mathrm{I}(1)$ \\
\hline LCONVUL & $-1.9752(0.2972)$ & $-9.0614\left(0.0008^{\star}\right)$ & $\mathrm{I}(1)$ \\
\hline
\end{tabular}

Note: $\left(^{*}\right)$ The rejection of the null hypothesis of unit root at the $5 \%$ significance level

The next step is to determine the long-run relationships between the variables using the Johansen cointegration test. Table 3, indicates the results of the long-run cointegration tests. The results show that both Johansen cointegration tests namely the Trace and Max-Eigen tests have statistic greater than the listed critical values, while the p-values of both tests are significant at 5 per cent significance level. This implies that there is at least one cointegrating equation, and thus conclude that there is a long-run relationship between the variables.

Table 3: Johansen co-integration results (Trace Statistic \& Max-Eigen Statistic)

\begin{tabular}{cccc}
\hline \hline $\begin{array}{c}\text { Hypothesized } \\
\text { No. of CE(s) }\end{array}$ & $\begin{array}{c}\text { Trace } \\
\text { Statistic }\end{array}$ & $\begin{array}{c}0.05 \\
\text { Critical Value }\end{array}$ & Prob. $^{* *}$ \\
\hline \hline None $^{*}$ & 85.5508 & 69.8188 & $0.0017^{*}$ \\
At most 1 & 54.3602 & 47.8561 & $0.0108^{*}$ \\
At most 2 & 27.7064 & 29.7970 & 0.0855 \\
At most 3 & 11.7166 & 15.4947 & 0.1710 \\
At most 4 & 2.21444 & 3.8414 & 0.1367 \\
\hline \hline Hypothesized & Max-Eigen & 0.05 & \\
No. of CE(s) & Statistic & Critical Value & $0.0412^{*}$ \\
\hline \hline None & 45.1906 & 33.8768 & 0.0654 \\
At most 1 & 26.6538 & 27.5843 & 0.2254 \\
At most 2 & 15.9898 & 21.1316 & 0.2467 \\
At most 3 & 9.50215 & 14.2646 & 0.1367 \\
At most 4 & 2.21444 & 3.8414 & \\
\hline \hline
\end{tabular}

Note: *denotes the rejection of the null hypothesis at the 0.05 level.

Equation (2) contains the result of the long-run relationship coefficients of the variables in the model. The equation indicates that there is a positive relationship between the dependent variable, consumer spending (LCONSP) and all of the other independent variables (LEMPL, LWAGES and LCPI) except for LCONVUL which has a negative relationship with LCONSP. The results, therefore, implies that a unit change (1\%) in emploment (LEMPL) could lead to an increase of $1.01 \%$ in consumer spending (LCONSP) which is an interestingly high coefficient indicating the importance of employment creation to boost consumer spending. In addition, a $1 \%$ increase in wages could result in an $0.71 \%$ increase in LCONSP; and a $1 \%$ increase in CPI could result in $0.53 \%$ change in consumer spending. Lastly a $1 \%$ decrease in consumer vulnerability could lead to a $0.64 \%$ increase in consumer spending. This outcome is in line with the findings of studies by ....... 
$L C O N S P=15.4537+1.0087 L E M P L+0.7142 L W A G E S+0.5320 L C P I-0.6428 L C O N V U L$ ...(2)

The next step in the process of analysing the relationships between the variables, and following the confirmation of long-run relationships via the Johansen co-integration tests, a VECM model was estimated. VECM has a dual purpose: to confirm the long-run equilibrium and also to estimate short-run dynamics. The error correction term (ECT) coefficients represent the speed of adjustment to long-run equilibrium. The variables achieve equilibrium, only if ECT coefficients are negative in sign and with significant t-values. Table 4 indicates the ECT and VECM results. Results indicate short-run relationships between the variables leading to adjustment towards the long-run equilibrium in LCONSP, LEMPL and LWAGES. The LCONSP equation has a negative ECT coefficient that is significant at 5 per cent significance level. This implies that a short-run shock to LCONSP should adjust to equilibrium taking approximately 11.8 quarters to move back to equilibrium. In addition, Table 5 also shows that LEMPL and LWAGES equations do have negative ECT coefficients at significance levels of $5 \%$ and therefor have a short-run relationship with consumer spending in addition to a long-run relationship. Further results from Table 4 regarding the VAR short-run analysis indicates that consumer spending has an impact on its own lag; as well as impacting on employment levels. Employment changes have an impact on consumer spending and $\mathrm{CPI}$, while changes in wages has a significant impact on employment. Changes in CPI has a significant impact on spending and wages consumer vulnerability, while consumer vulnerability significantly affects wages.

\section{Table 4: VECM results}

Error Correction: $\quad$ D(LCONSP) $\quad$ D(LEMPL) $\quad$ D(LWAGES) $\quad$ D(LCPI) $\quad$ D(LCONVUL)

\begin{tabular}{cccccc}
\hline \hline CointEq1 & -0.0846 & -0.0306 & -0.0511 & -0.0099 & 0.2813 \\
& $(0.0408)$ & $(0.0081)$ & $(0.0202)$ & $(0.0154)$ & $(0.0856)$ \\
& {$[-2.0738]^{*}$} & {$[3.7465]^{*}$} & {$[-2.5295]^{\star}$} & {$[-0.6405]$} & {$[3.2853]$} \\
D(LCONSP(-1)) & 0.5617 & 0.4203 & -0.0311 & -0.24581 & 1.1472 \\
& $(0.0882)$ & $(0.0893)$ & $(0.2206)$ & $(0.1688)$ & $(0.9347)$ \\
& {$[6.3675]^{*}$} & {$[4.7066]^{*}$} & {$[-0.1411]$} & {$[-1.4555]$} & {$[1.2273]$} \\
D(LEMPL(-1)) & 0.2773 & 0.0364 & 0.3356 & 0.4626 & 1.1351 \\
& $(0.1058)$ & $(0.1071)$ & $(0.2647)$ & $(0.2026)$ & $(1.1215)$ \\
& {$[2.6196]^{*}$} & {$[0.3402]$} & {$[1.2679]$} & {$[2.2830]^{*}$} & {$[1.0121]$} \\
D(LWAGES(-1)) & 0.0673 & 0.1323 & -0.0724 & 0.08332 & 0.5484 \\
& $(0.0472)$ & $(0.0478)$ & $(0.1182)$ & $(0.0904)$ & $(0.5008)$ \\
& {$[1.4238]$} & {$[2.7658]^{*}$} & {$[-0.6125]$} & {$[0.9207]$} & {$[1.0949]$} \\
D(LCPI(-1)) & -0.1175 & 0.0286 & 0.2974 & -0.0132 & 1.8041 \\
& $(0.0612)$ & $(0.0620)$ & $(0.1531)$ & $(0.1172)$ & $(0.6488)$ \\
& {$[-1.9192]^{*}$} & {$[0.4625]$} & {$[1.9424]^{*}$} & {$[-0.1128]$} & {$[2.7803]^{*}$} \\
D(LCONVUL(-1)) & -0.00301 & 0.0056 & -0.0745 & 0.0034 & -0.0758 \\
& $(0.0098)$ & $(0.0099)$ & $(0.0245)$ & $(0.0187)$ & $(0.1038)$ \\
& {$[-0.3070]$} & {$[0.5676]$} & {$[-3.0388]^{*}$} & {$[0.1844]$} & {$[-0.7301]$}
\end{tabular}

Note: * denotes significance at $5 \%$.

In addition, further short-run analysis is estimated using the Granger causality test methodology as presented in Table 5, indicating the direction of causality between the designated variables. Firstly, the causality results where the dependent variable is involved 
are discussed. LCONSP causes changes in LEMPL, LWAGES, LCPI but not LCONVUL; while LEMPL, and LCONVUL do cause changes or movements in LCONSP, all at $5 \%$ significance levels. Other causality results established are that LWAGES causes changes in LEMPL; LEMPL causes changes LCPI; and LCPI causes changes in LCONVUL.

Table 5: Granger Causality tests

\begin{tabular}{lccc}
\hline \hline Null Hypothesis: & Obs & F-Statistic & Prob. \\
\hline \hline LEMPL does not Granger Cause LCONSP & 88 & 5.83142 & $0.0043^{*}$ \\
LCONSP does not Granger Cause LEMPL & & 21.8936 & 2. - $^{*}$ \\
\hline \hline LWAGES does not Granger Cause LCONSP & 88 & 1.13696 & 0.3257 \\
LCONSP does not Granger Cause LWAGES & & 5.10152 & $0.0081^{*}$ \\
\hline \hline LCPI does not Granger Cause LCONSP & \multirow{2}{*}{88} & 1.35019 & 0.2648 \\
LCONSP does not Granger Cause LCPI & & 5.70920 & $0.0048^{*}$ \\
\hline \hline LCONVUL does not Granger Cause LCONSP & \multirow{2}{*}{88} & 3.41023 & $0.0377^{*}$ \\
LCONSP does not Granger Cause LCONVUL & & 1.41601 & 0.2485 \\
\hline \hline LWAGES does not Granger Cause LEMPL & \multirow{2}{*}{88} & 7.51232 & $0.0010^{*}$ \\
LEMPL does not Granger Cause LWAGES & & 2.64220 & 0.0772 \\
\hline \hline LCPI does not Granger Cause LEMPL & \multirow{2}{*}{88} & 1.65521 & 0.1973 \\
LEMPL does not Granger Cause LCPI & & 4.61039 & $0.0126^{*}$ \\
\hline \hline LCONVUL does not Granger Cause LEMPL & 88 & 6.41526 & $0.0026^{*}$ \\
LEMPL does not Granger Cause LCONVUL & & 3.49495 & $0.0349^{*}$ \\
\hline \hline LCPI does not Granger Cause LWAGES & 88 & 1.21057 & 0.3032 \\
LWAGES does not Granger Cause LCPI & & 0.86206 & 0.4260 \\
\hline \hline LCONVUL does not Granger Cause LWAGES & \multirow{2}{*}{88} & 5.47017 & 0.0859 \\
LWAGES does not Granger Cause LCONVUL & & 0.19059 & 0.8268 \\
\hline \hline LCONVUL does not Granger Cause LCPI & & 1.25279 & 0.2911 \\
LCPI does not Granger Cause LCONVUL & & 39453 & $0.0383^{*}$ \\
\hline \hline
\end{tabular}

Note: * $r e j e c t$ the null hypothesis of no Granger Causality at 0.05 significant level.

Finaly diagnostic tests are estimated to test if the model used in the study is stable and reliable with robust results. Table 6 indicates the results of the three tests and it could be stated that the model is clear from serial correlation, has no heteroscedasticity and the residuals are normally distributed.

Table 6: Consolidated diagnostic tests

\begin{tabular}{|l|l|l|l|}
\hline Test & Hypothesis & Probability & Decision \\
\hline Breusch-Godfrey test & No serial correlation & 0.1392 & No serial-correlation. \\
\hline White $(\mathrm{CT})$ test & No heteroscedasticity & 0.6755 & No Heteroscedasticity \\
\hline Jarque-Bera test & Residuals are normally & 0.3623 & Normally distributed \\
\hline
\end{tabular}


distributed

\section{CONCLUSION AND RECOMMENDATIONS}

Consumers in South Africa are under pressure due to high levels of structural unemployment, low wages and rising cost of living. The primary objective of the study was to analyse the relationship between consumer spending and various factors impacting on spending including employment levels, real wages, inflation and even the consumer vulnerability index as measured in South Africa. The results indicate that is it of importance that there is a decline in consumer spending in the presence of long term unemployment in South Africa. Since 2011 to 2019 , consumer spending only increased on average by $1.9 \%$ per annum. The findings reveal that consumer spending is affected on the long-run by all of the independent variables, with employment levels having the highest or largest impact with a coefficient of 1.01. The coefficients of real wages and inflation are 0.71 and 0.53 respectively. Long term unemployment remains to be the most important determinant of consumer spending. Monetary and fiscal authorities can work towards the reduction of interest rates, unemployment benefits should increase further and support for development of new businesses. On the short-run, similar results were found as on the long-run with employment and real wages affecting consumer spending. Regarding Granger causality, all of the independent variables affect changes in consumer spending on the short-run. The negative consequences of long term unemployment to consumer spending are clear, losing a job can lead to a decline in income levels in the short run. The study shows that consumer spending drops at the onset of unemployment.

The research had the aim to contribute to the knowledge regarding the factors impacting on consumer spending. Limited research is available on this topic especially for developing countries including for South Africa. As with most time series econometric studies, the study has some limitations. Additional variables or even different variables such as economic growth could be added to the model. Interesting results from the study is the positive coefficient of more than one between consumer spending and employment. Future research could include additional factors that have an impact on consumer spending and comparative and panel analysis of for example the BRICS countries. Employment, both formal and informal employment should be facilitated and promoted by means of the creation of an enabling environment through policy certainty and implementation. Also, skills training, especially technical skills training should be prioritised, small business development should be supported, income levels for the lower income earners could be increased to enhance consumer spending and ultimately contributing to economic growth.

\section{REFERENCES}

Agarwal, S., Liu, C. \& Souleles, N.S. 2007. The Reaction of Consumer Spending and Debt to Tax Rebates-Evidence from Consumer Credit Data. Journal of Political Economy, 115(6): 986-1019.

Alisa, M. 1990. Analysis of the Philips curve. Journal of Economic Sciences, 4(1): 222-228.

Angeletos, T., Meghin, C., Pistaferi, T. \& Arthur, S. 2001. Unemployment and real income. Journal of Economics, 111(6): 631-639.

Bachmann, O., James, J., Reid, M. \& Sandom, A. 2015. Ghana as a developing country. Journal of International Economic Studies, 87(1): 44-47. 
Baker, S.R. 2015. Debt and the consumption response to household income shocks. Available at SSRN 2541142.

Barello, S.H. 2014. Consumer spending and US employment from the 2007-2009 recession through 2022. Monthly Labour Review, 137, 1.

Bhorat, H. 1991. Unemployment and the informal sector, South African Journal of Economics, 67(2): 14-18.

Brooks, C. (2014). Introductory econometrics for finance. Cambridge. University Press.

Gallegati, M., Gallegati, M., Ramsey, J. B. \& Semmler, W. 2011. The US wage Phillips curve across frequencies and over time. Oxford Bulletin of Economics and Statistics, 73(4): 489-508.

Ganong, P. \& Noel, P. (2015). How does unemployment affect consumer spending?. Unpublished manuscript, Harvard Univ., Cambridge, MA. http://scholar.harvard. edu/files/ganong/files/ganongmpnemploymentpending.pdf.

Ganong, P. \& Noel, P. (2019). Consumer spending during unemployment: Positive and normative implications. American Economic Review, 109(7): 2383-2424.

Hausman, I. \& Wieland, T. 2014. The relationship between inflation and consumer spending in Ghana. Journal of Political Economy, 37(2): 44-46.

International Labour Organisation (ILO). 1996. Restructuring the labour market: the South African challenge. An ILO country Review. ILO, Geneva.

International Labour Organisation (ILO). 2000. Forces in the labour market : the South African platform. An ILO country Review. ILO, Geneva.

International Labour Organisation (ILO). 2017. Unemployment ratings. Review on Economic figures of Unemployment. ILO, Geneva.

Kanawo, J. \& Lalumia, P. 2004. Unemployment and spending in South Africa: A spatial approach, Working paper 99-12. University of Oxford.

Kitson, M. 1997. The fiscal and distributional implications of job generation. Cambridge Journal of Economics,24(1): 20-24.

Knight, J.B. 1982. The nature of unemployment in South Africa. South African Journal of Economics. 50(1): 1-2.

Kreishan, F. 2011. Unemployment: Macroeconomic performance and the labour Market. $1^{\text {st }}$ ed. New York.:Oxford University press.

Mankiw, N.G. 1985. Small menu costs and large business cycles: a macroeconomic model. The Quarterly Journal of Economics, 100(2): 529-38.

Mian, A. \& Sufi, A. 2014. What explains the 2007-2009 drop in employment? Econometrica, 82(6): 2197-2223.

Midrigan, V. \& Philippon, T. 2011. Household leverage and the recession. EconPapers. https://econpapers.repec.org/paper/nbrnberwo/16965.htm

Oswald, S.R. 2009. Unemployment in a worsening labour market. Journal of Social Science, 96(1): 44-47. 
Parker, J.A., Souleles, N.S., Johnson, D.S. \& McClelland, R. 2013. Consumer Spending and the Economic Stimulus Payments of 2008. American Economic Review, 103(6): 253053.

Ross, J. W., Weill, P., \& Robertson, D. 2006. Enterprise architecture as strategy: Creating a foundation for business execution. Harvard Business Press.

Rode, S. 2012. Advanced macroeconomics. Bookboon.

SARB. 2019. Economic Data. Pretoria. South African Reserve Bank.

Sarno, L., \& Taylor, M.P. 2002. Purchasing power parity and the real exchange rate. IMF staff papers, 49(1): 65-105.

Shapiro, M.D. \& Slemrod, J. 1993. Consumer response to the timing of income: Evidence from a change in tax withholding (No. w4344). National Bureau of Economic Research.

Statistics South Africa (StatsSA), 2018. Household survey statistical release 317. http://www.statsSA.gov.za.statistical-release.htm. Date of access: 16 February 2019.

Stephens, M. 2011. The long run consequences of unemployment in consumer spending. Review of Economics and Statistics. 82(1): 17-22.

Thomson, T. 1998. Spending versus Unemployment. Journal of the Political Economy. 101(7): 1176-1194.

Thoodossiou, I. 1998. The effect of low pay and unemployment on psychological wellbeing: a logistic regression approach. Journal of Health Economics, 17(1): 85-104.

Toossi, M. (2002). Consumer spending: An engine for US job growth. Monthly Labour Review, 125, 12.

TradingEconomics. 2019. Income inequality and Gini Coefficient: Country comparisons. https://tradingeconomics.com/. Date of access: 12 September 2019.

Wilkelmann, L. 1998. The unemployed are unhappy? Evidence from panel data. Economica, 65 (257):1-5.

Zheng, Z., \& Henneberry, S.R. 2011. Household food demand by income category: evidence from household survey data in an urban Chinese province. Agribusiness, 27(1): 99113. 